WellBeing International

WBI Studies Repository

1986

\title{
Wildlife Conservation and Animal Rights: Are They Compatible?
}

Michael Hutchins

New York Zoological Society

Christen Wemmer

Smithsonian Institution

Follow this and additional works at: https://www.wellbeingintlstudiesrepository.org/acwp_wmm

Part of the Animal Studies Commons, Bioethics and Medical Ethics Commons, and the Other Ecology and Evolutionary Biology Commons

\section{Recommended Citation}

Hutchins, M., \& Wemmer, C. (1986). Wildlife conservation and animal rights: Are they compatible?. In M.W. Fox \& L.D. Mickley (Eds.), Advances in animal welfare science 1986/87 (pp. 111-137). Washington, DC: The Humane Society of the United States.

This material is brought to you for free and open access by WellBeing International. It has been accepted for inclusion by an authorized administrator of the WBI Studies Repository. For more information, please contact wbisr-info@wellbeingintl.org.

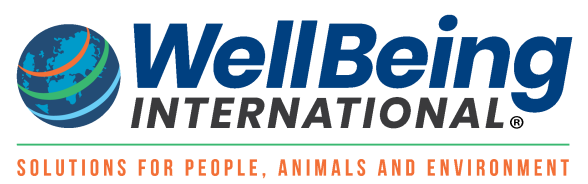




\title{
WHDLIFE CONSERVATION AND ANIMAL RIGHTS: ARE THEY COMPATIBLE?
}

\author{
Michael Hutchins ${ }^{1}$ and Christen Wemmer ${ }^{2}$
}

\section{Introduction}

In the history of Western civilization, nature was viewed primarily in utilitarian terms (Shaw 1974; White 1967). Wild animals were a source of food, clothing, and transportation, and wilderness was something to be "tamed" for the collective benefit of mankind. Indeed, the Biblical injunction from Genesis 9 was "And the fear of you and the dread of you shall be upon every beast of the earth... into your hands they are delivered." Within the last century, however, perceptions have begun to change. We have now seen the emergence of a broad-based coalition of individuals and organizations dedicated to the goal of preservation, rather than exploitation. The end result has been the formation of something completely novel to Western thought-an environmental ethic.

Aldo Leopold is universally recognized as the founding father of modern environmental ethics. His "land ethic" (Leopold 1949) is a classic statement of environmentalist philosophy, and one of the first to accord direct moral consideration to non-human animals (Callicott 1980). More recently, however, we have seen the emergence of a new ethical tradition, known as "animal rights" or "animal liberation" (Singer 1975; Regan 1983; Midgley 1983). This movement is a variation of the humane ethic, which seeks to eliminate the pain and suffering of non-human animals, especially that which results from human cruelty and indifference. Radical animal liberationists draw heavily upon the metaphors of political liberalism, claiming that animals, not unlike women and racial minorities, should be accorded equal rights, regardless of species. Extremists have demanded equal moral consideration for farm animals and other "enslaved and oppressed" non-human beings (Singer 1975; Regan 1983).

The purpose of this paper is to explore the philosophical tenets of the animal rights/humane ethic as they relate to the environmental ethic and, more specifically, as they relate to wildlife management and conservation. The two ethics will be compared in an effort to identify potential sources of conflict. Recent criticisms of the animal rights ethic, most notably by Fox (1978, 1979), Rodman (1977), Callicott (1980), Gunn (1980), and Hutchins et al. (1982) have identified several major discrepancies. The implications of these differences will be discussed. 


\section{Environmental Ethics and Animal Rights}

Before discussing potential sources of conflict between the environmental/ conservation and animal rights/humane ethics, it will first be necessary to examine the two viewpoints in more detail. Both ethics share a concern for wild animals. Differences between the two can best be understood through a closer examination of their reasoning.

The primary goal of the environmental/conservation ethic is to preserve naturally occurring biological diversity (Ehrlich and Ehrlich 1981; Gunn 1980; Myers 1980). The term "natural" is used here to distinguish between diversity that has occurred as a result of natural evolutionary/ecological processes (i.e., speciation, colonization, "natural" extinctions), and that which has occurred because of recent human interventions (i.e., species introductions, humancaused extinctions). Aldo Leopold once said that "A thing is right if it tends to preserve the integrity, stability, and beauty of the biotic community. It is wrong when it tends to do otherwise" (Leopold 1949). Thus, the biological richness of an ecosystem, as characterized by the number and variety of species it supports, is seen as intrinsically good. Conversely, changes in naturally occurring biological diversity that occur as a result of human activities (either directly or indirectly) are perceived as intrinsic evils. Note that it is naturally occurring diversity that is important here, rather than absolute numbers of species. Tundra, for example, is relatively devoid of life when compared with tropical rain forest. However, it does support a characteristic assemblage of species, and, according to the environmental/conservation ethic, it is this naturally occurring biotic community which should be preserved. The reader should also recognize that the aim of conservation is not to prevent change-ecosystems and species will change even in the absence of human interference. Indeed, evolution through natural selection is a dynamic, rather than a static process. According to Ehrenfeld (1972, p.7), the broad goal of conservation is "...to ensure that nothing in the existing natural order is permitted to become permanently lost as the result of man's activities except in the most unusual and carefully examined circumstances." Some exceptions have been made, for example, in the case of certain disease organisms, such as smallpox (Fenner 1980).

Species or ecosystems do not warrant moral consideration according to the animal rights/humane ethic, although they may be said to have "inherent value" (Feinberg 1978; Regan 1983). Thus, the humane moralists argue that individual organisms, rather than species or ecosystems, should be the focus of our ethical concerns. Furthermore, they argue that sentience- the capacity to experience pain - is the only relevant characteristic needed by organisms to merit full moral consideration (Singer 1975; Regan 1983). They contend that if non-human animals have the capacity to experience pain, then their suffering should be as important a matter of ethical concern as that of our fellow humans. That non-human animals may be incapable of reason, speech, forethought, or self awareness is considered irrelevant. After all, some classes of humans, (e.g., infants, and the severely mentally retarded) do not possess 
these abilities, and yet are accorded rights. The argument that human needs should take precedence over those of sentient non-humans is viewed as "speciesism" - a form of prejudice analogous to chauvinism, racism, or sexism (Singer 1975; Regan 1983; Midgley 1983). Thus, individual animals are seen as having a "right to life" and, except in very special cases, any attempt to kill them or to cause them to suffer pain is considered to be morally unjustifiable. The logical consequence of such an ethic is, of course, obligatory vegetarianism (Regan 1983; Singer 1975). (However, note that eating carrion does not involve the voluntary infliction of pain or death, and apparently would not be restricted by the animal rights/humane ethic.)

In this regard, it is important to recognize several degrees of rigor in the interpretation of the animal rights/welfare doctrine. Adherents to the most extreme view contend that there are few circumstances that could justify the killing of sentient animals by humans (Singer 1975; Regan 1983; Midgley 1983). However, the more liberal view is that humane and painless killing of animals is sometimes a regrettable necessity. The Humane Society of the United States, for instance, advocates the humane disposal of homeless dogs and cats. Implicit in such a policy is the assumption that death is a better alternative than the marginal quality of life these animals would experiencecone to a lack of human care and companionship (W/right 1978).

At first glance, the philosophical bases of the environmental/conservation ethic and the animal rights/humane ethic seem compatible. The welfare of animals has been a concern of both, but despite this common ground, profound differences exist. Callicott (1980) has compared the "land ethic" of Aldo Leopold (1949) with the "humane ethic" of Peter Singer (1975). While only sentient animals are afforded moral standing according to the humane ethic, the land ethic is more holistic, focusing not only on animals (both sentient and non-sentient), but also on plants, soils, waters, and ofher non-living things. While philosophical differences exist within various factions of both the environmental/conservation and the animal rights/welfare movements, we see their radically divergent emphasis on the individual as opposed to the population, species, or ecosystem as a crucial issue.

Ideological differences between the two ethics are evident in their contrasting view of the endangered species problem. While both ethics favor saving endangered animals, they differ in their reasons for doing so. Regan (1983, p. 360) argues that we should conserve endangered species "... not because the species is endangered, but because the individual animals have valid claims, and thus rights against those who would destroy their natural habirat, for example, or who would make a living off their dead carcasses through poaching and traffic in exotic animals, practices which unjustifiably override the rights of these animals." Thus, all sentient animals, regardless of species, rarity or other considerations, are to be given equal moral consideration according to the rights view.

In contrast, proponents of the environmental/conservation ethic argue that endangered species should be given special status solely because of their 
scarcity (Gunn 1980). That is, extraordinary efforts should be made to preserve rare species, especially when an organisin has become rare due to some action on the part of humans (e.g., as a result of pollution, habitat alteration, or over-hunting). This follows from the underlying rationale that naturallyoccurring biological diversity is intrinsically good, and that it provides a measure of the "health" of an entire ecosystem (Leopold 1949). Again, the focus is on the population, species, or ecosystem as a whole, rather than on individual organisms. There is a political element at play here as well. To the conservationist, endangered species have become representatives of the process of habitat degradation. While complexity in natural ecosystems is generaliy sufficient to weather the loss of some species before checks and balances are thrown out of equilibrium, it would be politically unwise to forego any loss of biological diversity without a fight. The recent controversy involving the snail darter is a case in point (Ehrlich and Ehrlich 1981).The environmental/conservation ethic is also based on the realization that the components of an ecosystem (both living and non-living) are often intricately interrelated, and that an instability in these elements can have far-reaching, and sometimes degrading consequences (Leopold 1949; Dasmann 1978; Fox 1978; Ehrlich and Ehrlich 1981).

\section{Potential Gources or Confliot}

Clearly, the animal rights/humane ethic and the environmental/conservation ethic will lead to the same decisions in many situations. For example, both ethics would consider it wrong for humans to destroy wildlife habitat, or to pollute it with chemicals and wastes. But, when the two viewpoints are compared, it is evident that disagreements will arise when the "rights" of individual organisms come into conflict with the preservation of populations, species, or ecosystems. As Regan (1983, p. 361) has pointed out, one implication of the more holistic environmental/conservation ethic is "... that the individual may be sacrificed for the greater biotic good." Regan opposes such actions, because they deny "... the propriety of deciding what should be done to individuals who bave rights by appeal to aggregative considerations, including, therefore, computations about what will or will not maximally contribute to the integrity, stability, and beauty of the biotic community." Furthermore, he dismisses any attempt to subvert the rights of individual organisms to those of the species, or ecosystem as "environmental fascism."

There are many circumstances in which the "rights" of individual organisms may come into conflict with the preservation of populations, species, or ecosystems. We have chosen three such cases for more detailed consideration: (1) Problems of population regulation, (2) Incentives for wildlife conservation, and (3) Conservation-related research that harms individual animals.

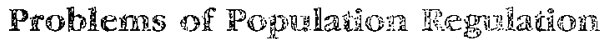

The culling of wild animal populations is a particularly sensitive issue for proponents of both the animal rights/humane and environmental/conservation 
ethics. Though their reasons may differ, proponents of both ethics are strongly opposed to the senseless killing of non-human animals. But what should be done in those situations where animals become too numerous for their own good, or for the good of the population, species, or ecosystem as a whole?

Overpopulation is a difficult concept to define. The phrase "too many animals" does not do justice to the complexity of the phenomenon. Caughley (1981) recognizes four different classes of overpopulation: (1) the animals are threatening human life or livelihood, (2) the animals are depressing the densities of favored species, (3) the animals are too numerous for their own good, and (4) the system of plants and animals is not in equilibrium, thus resulting in an alteration of the entire ecosystem. Of the four classes of overpopulation, numbers 3 and 4 appear to have the most potential for generating conflict between the two ethics and will, therefore, be discussed in greater detail.

When does a population of animals become too large for its own good? Generally, such a situation exists when individuals become so numerous that their habitat can no longer support them. An excellent example is provided by the Mule deer (Odocoileus bemions) inhabiting the Kaibab Plateau of northern Arizona (Rasmussen 1941). The plateau was set aside as a game reserve in 1906 , and a program of predator removal was initiated to provide more deer for recreational hunters. During a 25 -year period, over 6,000 major predators were killed, including nountain lions, wolves, coyotes, and bobcats. The wolf (Canis lupus) was completely elininated.

Following the eradication of predators, the deer began to multiply rapidly. The population, which had been estimated at 4,000 individuals in 1906 , grew to between 60,000 and 70,000 individuals by 1923. As their numbers expanded, the animals overgrazed the vegetation, thus resulting in severe food shortages. In September, 1923, it was estimated that between 30,000 and 40,000 deer were starving. In 1925, the population "crashed" and nearly two-thirds of the herd died. By 1939, only 10,000 individuals remained.

This pattern of rapid population growth, followed by an equally rapid decrease is known as an "eruption." Caughley (1976) suggested that eruptions are characteristic of populations of large herbivores. However, all recorded instances of this phenomenon in North America have been preceded by some form of human intervention (Peek 1980). The Kaibab deer, for instance, are a classical example of poor wildlife management; elimination of the deer's predators subsequently resulted in overpopulation, habitat degradation, and widespread starvation. Unfortunately, similar situakions exist to this day in many parts of the continental U.S. (Iker 1983; Klein 1981). As a result, some wildlife managers and conservationists have recommended that populations of deer and other large herbivores be controlled through culling. Animal rights advocates, on the other hand, have traditionally been anti-hunting, and recent attempts to control animal populations by killing have been vigorously opposed, whether they be in national parks or on other federally controlled lands (e.g., Grandy 1982; The Humane Society Vews 1983). Indeed, 
Regan (1983, p. 361) has stated that "With regard to wild animals, the policy recommended by the rights view is: let them be!" But what are the consequences of inaction?

When a population of herbivores overshoots its food resources, individual animals can be expected to suffer an increased starvation rate (Klein 1968; Leopold et al. 1947; McCullough 1979; Taylor and Hahn 1947). Moreover, such conditions also lead to increased mortality and suffering due to disease, parasitism, and aggression-related injuries (Cheatum 1951; Christian and Davis 1964; Wilson and Hirst 1977). If a major goal of the animal rights/humane ethic is to reduce pain and suffering, then how can such situations be tolerated?

Proponents of the animal rights/humane ethic may be suspicious of this argument, since it is the same one used to justify recreational hunting (Lyons 1978; Hope 1974). However, the goals of the environmental/conservation ethic are different than those of the majority of wildlife managers and hunters. Wildlife managers are also considered among the environmentally aware. However, by definition, a manager is one who makes "judicious use of means to accomplish an end" (Webster's Seventh New World Collegiate Dictionary). Thus, wildlife managers make decisions which affect the environment, generally to favor the productivity of specific game animals. Furthermore, they tend to focus on disturbed rather than on natural environments, and view the cropping of overabundant animals as legitimate and necessary. Though the environmental/conservation ethic does not prohibit recreational hunting per se (National Wildlife 1971; Callicott 1980), it also does not condone widespread environmental manipulations that favor specific species at the expense of others. Many hunters and wildlife managers do not view such manipulations as being ecologically disruptive when, in fact, they often are (Hope 1974).

In recent years, some biologists have argued for more noninterventional wildlife management policies, especially in larger national parks, i.e., those which contain relatively complete ecosystems (Houston 1971, 1982). Noninterventional or "natural" managernent policies involve a "hands-off" attitude similar to that expounded by radical animal rights activists (e.g., Regan 1983). However, one result of such a policy is that natural regulatory processes are allowed to operate regardless of the consequences for individual animals. In Yellowstone National Park, for example, 200 bighorn sheep (Ovis canadensis) recently contracted keratoconjunctivitis, an eye disease commonly known as pinkeye (Meagher 1982; Robbins 1984). Nearly $85 \%$ of these individuals became blind, and subsequently died as a result of starvation or injuries sustained during falls. Although the animals were admittedly suffering, Park Service officials never considered treating them with antibiotics. Since the disease was considered to be naturally occurring, it would have conflicted with their policy of non-intervention. The philosophy espoused by the U.S. National Park Service is that pristine ecosystems exist in an equilibrium state in which human impact on energy flow should be minimized at all times (Houston 1971). The Park Service view is that humans should not interfere with the workings of nature, which are preceived in neutral terms, without 
moral judgement (see Gould 1982). Not surprisingly, this and other recent decisions by wildlife managers have been highly controversial (Blonston 1983; Chase 1986; Robbins 1984).

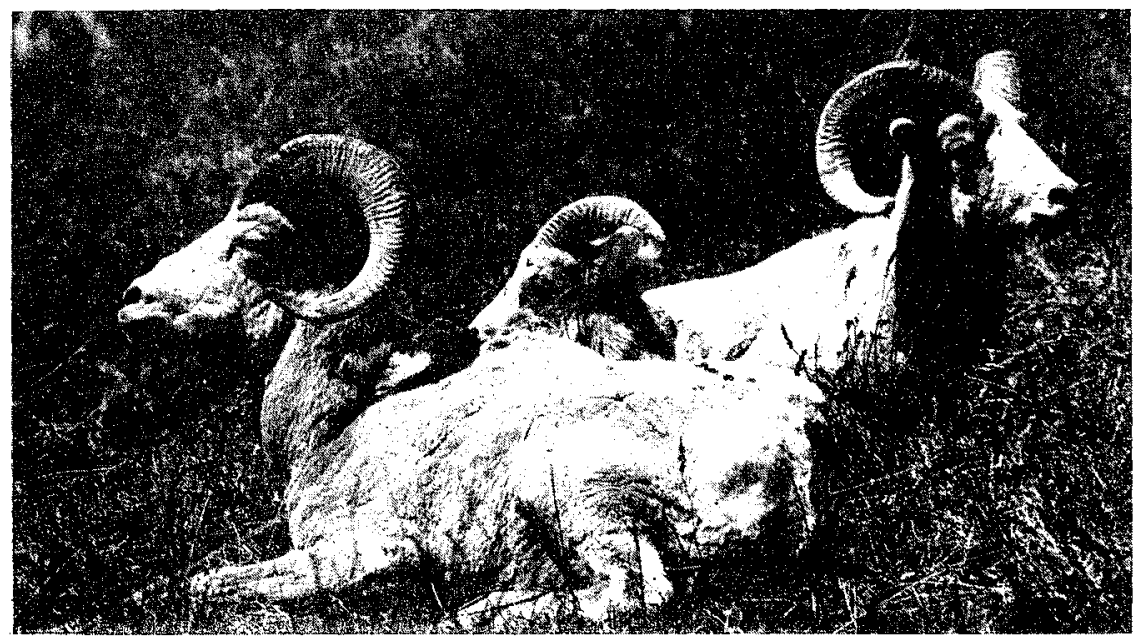

Figure 1. When some bighorn sheep in Yellowstone National Park contracted a blinding eye disease, Park Service personnel made no attempt to intervene. One implication of non-interventional or "natural" management policies is that normal regulatory processes, such as disease and predation, are allowed to operate regardless of the consequences for individual animals. (Photo: Gerry Ellis)

Despite Regan's (1983) plea that wild animals be left alone, it would seem that even non-interventional management policies might conflict with the rights ethic, or at least create that perception in the public mind. If we are to accept the proposition that all sentient beings have a "right to life," then the logical conclusion is that we should intervene in those cases in which sentient animals are suffering from starvation or disease (but, see Feinberg 1978 for an alternative viewpoint). In fact, animal rights/welfare organizations are generally among the first to recommend supplemental feeding for undernourished wild animals (Grandy 1982; Iker 1983). However, such actions are often in conflict with the environmental/conservation ethic. Supplemental feeding may increase the probability that animal populations will eventually overshoot their food resources (figure 2; Robinson et al. 1980). Furthermore, by concentrating the animals at feeding stations, such practices may also increase the incidence of disease, or intensify rates of habitat alteration (Madson 1986). The obvious danger in such a policy is that short-sighted empathy can lead to much greater suffering, not only for the animals of interest, but also for the ecological community as a whole (see Hardin 1974 for a similar argument regarding human population problems). 


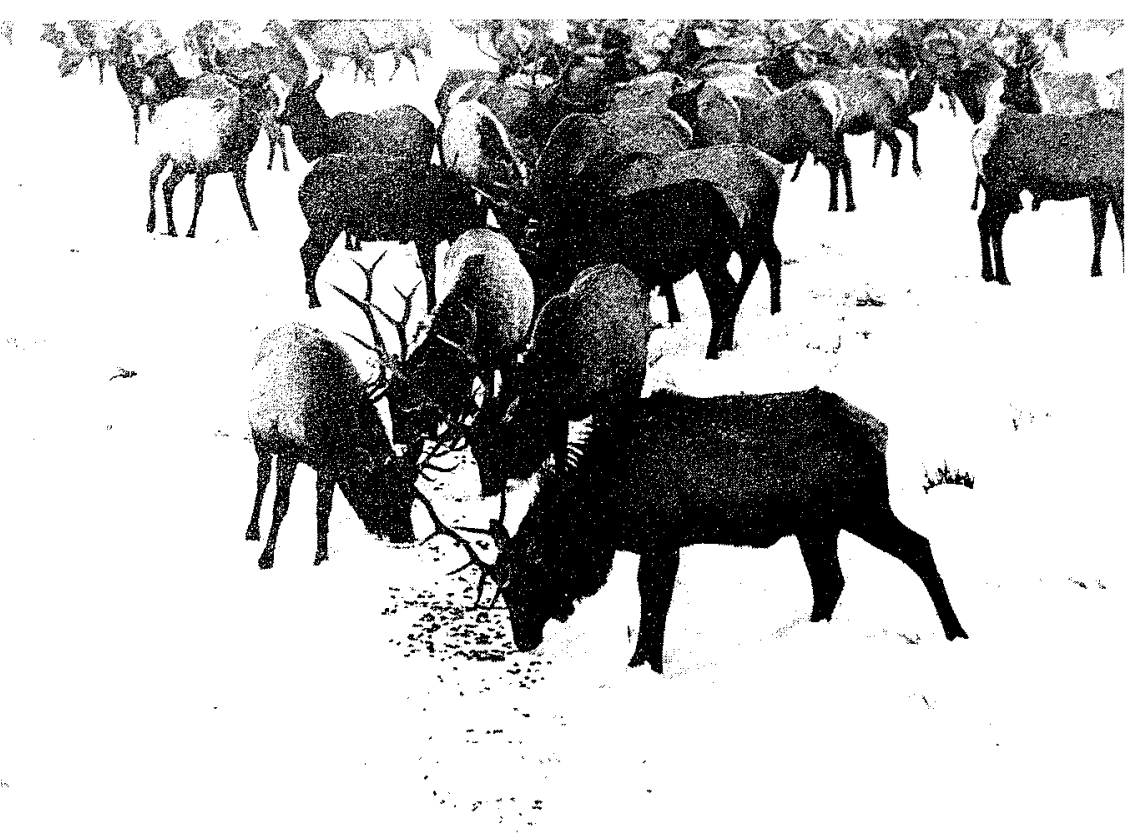

Figure 2. Supplemental feeding of elk in Wyoming. Unless artificial feeding is combined with a regular program of population reduction, the animals may overshoot their food resources, degrade their habitat, and suffer an increased rate of starvation. (Photo: John Wilbrecht, U.S. Fish and Wildife Service.)

The animal rights/humane ethic is clear on its position regarding humananimal relationships, but it is unclear with regard to pain and suffering inflicted upon animals by animals (Hutchins et al. 1982). In general, the doctrine aims to limit human behavior with the objective of minimizing or eliminating human-caused pain or discomfort to other creatures. At least among some animal rights advocates, what predatory animals do to their prey is beyond the realm of concern, presumably because it is done by "innocent killers," lacking in malicious intent or knowledge of the ethical consequences of their actions (Regan 1983; Feinberg 1978). This is an enlightened view compared to attitudes of the past when the conduct of animals was morally appraised (Beach 1975), and predators, such a wolves, were persecuted as "blood-thirsty killers" or "allies of the devil" (Lopez 1975). However, such arguments also open the animal rights movement to logical criticism. From the standpoint of the individual, pain is pain, regardless of the "intent" of the predator. In addition, predation is not the only way that one organism can have a detrimental effect on another. Indeed, one critical weakness of a view of nature that stresses individual rights is that it fails to recognize the interdependencies that exist within natural ecosystems. 
Thus, if a population of herbivores becomes so numerous that it degrades its habitat, many other organisms may suffer as well. For example, elephants (Loxodonta a. africana) have become a serious conservation problem in African national parks (figure 3; Van Wyk and Fairall 1969; Buechner and Dawkins 1961; Laws 1970; Cumming 1981). The destruction of woody vegetation by elephants is causing widespread habitat alteration, including the conversion of woodlands to open grassland or semi-desert. Consequently, many other species of animals can no longer utilize these areas, and may be caused to suffer as a result (Laws 1970; Pienaar 1969). Perhaps even more importantly, such habitat alteration increases the probability of local extinctions. Those responsible for our wildlife and ecosystems are thus forced to make difficult decisions about how to promote the "greatest good."

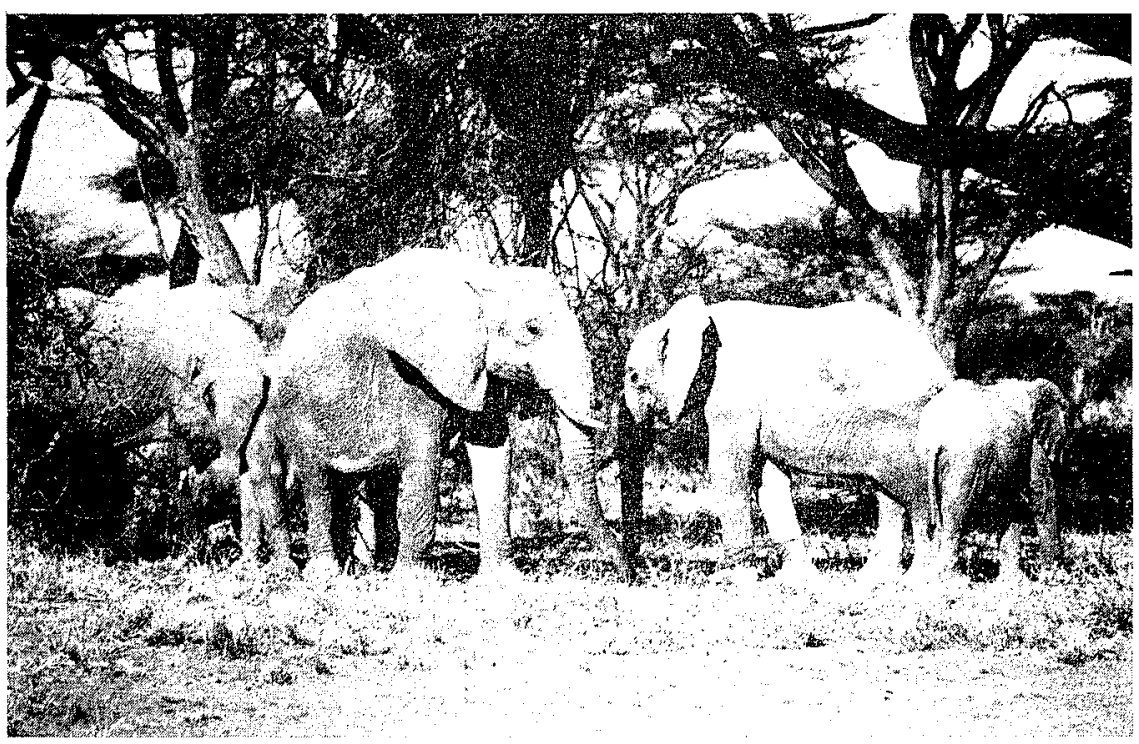

Figure 3. Elephants have become a serious conservation problem in African national parks. With their movements restricted by park boundaries, these large herbivores overgraze the vegetation and convert woodland habitats into grasslands or semideserts. (Photo: Henry Klein)

The so-called "elephant problem" is due largely to human overpopulation (Laws 1970). The progressive use of land by people for living space and agriculture has restricted many large mammals exclusively to national parks. One result is that elephant populations are no longer regulated by natural processes, such as dispersal. Thus, the animals may become so numerous that they degrade their own habitat. Conservationists have generally agreed that the only solution to this problem is culling (Caughley 1976; Haigh 
et al. 1979; Laws 1970, 1974; Pienaar 1969; Younghusband and Myers 1986). Practical considerations make it difficult, if not impossible, to capture and translocate large numbers of adult elephants. Furthermore, most African national parks have more than enough elephants already, so there is really no place for the animals to go. (Note that immature elephants are sometimes captured and transported to underpopulated areas for release, see Haigh et al. 1979.)

How do wildlife managers decide when intervention is required? The precise answer to this question may never be known (McCullough 1979; Noy-Meir 1981; Sinclair 1981), although some estimates have been obtained through mathematical modelling. At any given point in time, the biomass of herbivores and the biomass of the vegetation are unlikely to be in perfect equilibrium, and there are frequent perturbations in the system (Noy-Meir 1981; Sinclair 1981). But, as Caughley (1970) has pointed out, unless the displacement becomes very large (more than $30 \%$ or so), little can be gained by artificial reductions of population size. If, however, the displacement from equilibrium is extreme, it can result in irreversible changes in vegetation and soils, and these are the conditions that are most likely to lead to extinctions. Unfortunately, such generalizations seldom apply in specific cases. The degree of environmental alteration caused by grazing animals can be affected by many variables, such as the type of vegetation, amounts of precipitation, and the size of the park or reserve (Laws 1970).

So far, we have limited our discussion to problems of overpopulation in indigenous animals. However, a related topic that deserves attention is that of introduced or "exotic" species. One of the many ways in which humans alter their environment is by transporting organisms across natural barriers to dispersal. Colonizing peoples have traditionally attempted to modify their new settings by releasing animals (both domestic and wild) that are native to their homelands (Laycock 1966). Many introduced forms have flourished in their new settings, and in fact there are several widespread cultivars whose origins are unknown, so vicarious was their dissemination.

The introduction of exotic mammals has often been associated directly or indirectly with pervasive changes in native fauna and flora (Courtney 1978; Courtney and Ogilvie 1971; deVos and Petrides 1967; Laycock 1966; Hutchins et al. 1982). The problems caused by introduced species are not unlike those that occur when indigenous animals become overpopulated. However, because these organisms are not native to the host ecosystem, their destabilizing effects are often greatly accentuated. It appears that island ecosystems are particularly vulnerable to disruption (Coblentz 1978; Holdgate 1967). New Zealand, for example, is an island nation in which an assortment of alien herbivores (e.g., the brush-tailed possum, red deer, sika deer, and Fimalayan tahr) have virtually annihilated the native woodland communities (Howard 1964, 1967; Wardle 1974). The region's natural vegetation evolved in the absence of heavy grazing pressure, and therefore did not develop chemical or physical adaptations for protection. Plants with a history of 
exploitation by herbivores tend to evolve adaptations such as toxins, thorns, or rapid growth and reproductive rates to protect them from their "predators" (Janzen 1978; Pianka 1983).

Conservationists have argued that populations of destructive exotics be controlled through culling, especially in national parks, where the animals are threatening native fauna and flora (Allen et al. 1981; Laycock 1966, 1984). Such examples illustrate the potential for conflict between the environmental/ conservation and animal rights/welfare movements (Hutchins et al. 1982). Recent attempts to cull populations of feral burros in Grand Canyon National Park, for instance, have been opposed by animal rights/welfare advocates (figure 4; Laycock 1974; Stocker 1980; Reiger 1978). This occurred despite evidence that the foraging and trampling activities of burros are altering fragile desert habitats, and may be contributing to the decline of the native bighorn sheep (Ovis canadensis) (Carothers et al. 1976; Hanley and Brady 1977; Hansen 1980; Walters and Hansen 1978; Schectman 1978; Tennesen 1975; U.S. Dept. of the Interior 1980).

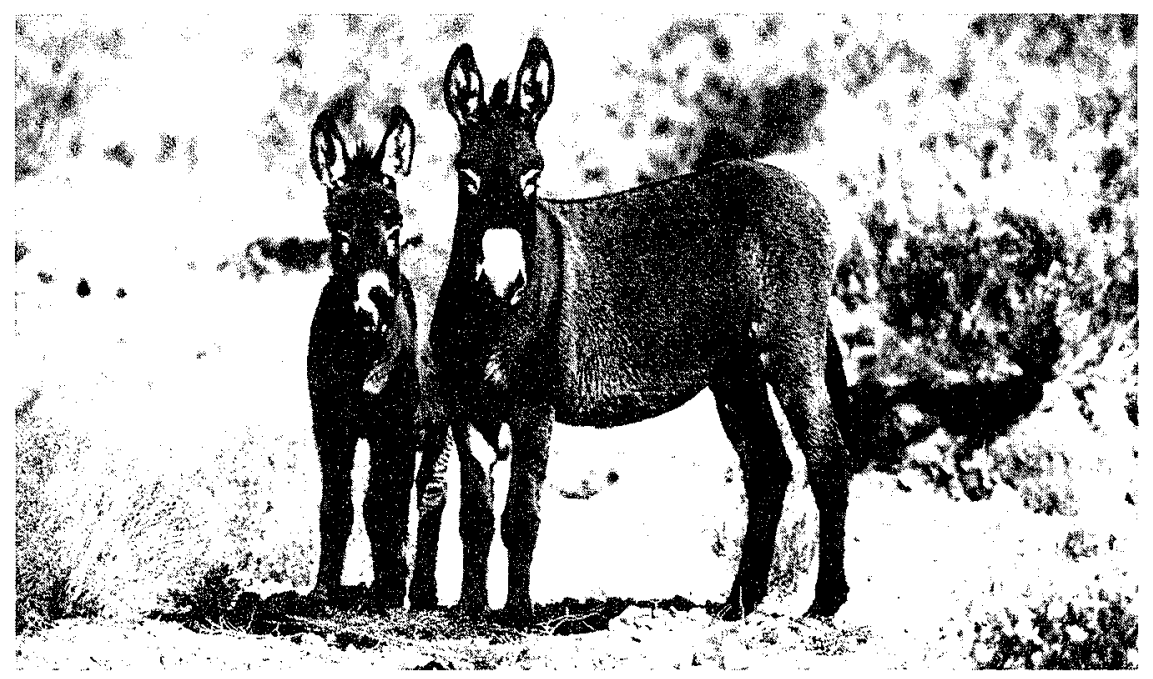

Figure 4. Burros were brought to North America by the Spanish in the sixteenth century. Thousands now roam the Southwestern United States, where they compete with native wildlife and alter fragile desert ecosystems. (Photo: Gerry Ellis)

Much of the controversy surrounding the artificial regulation of animal populations has focused on the means, rather than on the ends (Hutchins et al. 1982). Understandably, animal rights/welfare advocates are opposed to any solution which involves killing, yet current methods of population control may involve shooting, poisoning, trapping, or the introduction of disease (Anderson 1971; Fenner and Ratcliffe 1965). 
In arguing against the control of certain exotic animals, some animal rights/welfare advocates have questioned whether any benefits would actually result from such actions. However, there are several instances in which the control or elimination of exotic mammals has had beneficial effects. When small exclosures were erected to study the effects of feral goats on native flora in Haleakala National Park, Hawaii, the seeds of a heretofore unknown leguminous plant began to germinate (Baker and Reeser 1972). Similarly, eradication of feral goats in the Galapagos Islands, Ecuador, resulted in the rapid regeneration of native plants (Hamann 1979). The elimination of feral rabbits from Laysan Island in the leeward Hawaiian chain saved the endemic Laysan teal (Anas laysanensis) from almost certain extinction (Warner 1963). At the time the rabbits were eliminated, the birds' population had been reduced to less than seven individuals. Now there is a healthy population.

Population regulation will probably continue to be a point of contention between animal rights/welfare advocates and conservationists. However, recent technological advances may help to alleviate some of this conflict. There has, for example, been increasing interest in the development of non-lethal methods of population control, such as tubal ligation, castration, chemosterilization or mechanical devices that prevent conception (Davis 1961; Johnson and Tait 1983; Matsche 1976; Singer 1975; Turner 1984).

Implanted or orally administered hormones are commonly used to inhibit reproduction in zoo animals, and this has reduced the need for euthanasia (Seal et al. 1976; Whitlock 1978). Unfortunately, the use of similar procedures for wild animals is often fraught with complications. For example, many of these methods require capturing and handling the animals, and this may lead to considerable psychological and physical trauma (figure 5; see "Conservation Research and Humane Concerns," below). Hormone implants and orally administered reproductive inhibitors often require repeated applications, sometimes on a daily basis. In addition, these methods can have many deleterious side effects (Matsche 1977a, 1977b, 1980; Remfrey 1978; Seal et al. 1976). Methods involving surgical procedures may lead to infection or death (Zwank 1981).

Even if some animals can be permanently sterilized, social factors may limit the effectiveness of control (Johnson and Tait 1983). Some rodents, for example, are poor candidates for the use of chemosterilants because of their promiscuous breeding behavior. In high density populations, a female rat may mate with as many as 20 different males. In fact, one study found that reproduction was not curtailed in a rat colony in which $85 \%$ of the males were surgically sterilized (Kenelly et al. 1970). Wild horses, on the other hand, have proven to be excellent candidates for reproductive inhibition. Horses are highly polygynous, and a single stallion may mate with from two to eleven mares. Since stallions vigorously defend their harems, the use of chemosterilants can have a significant impact on reproduction. One study obtained an $80 \%$ decrease in births by administering long-acting antifertility drugs to specific males (Turner 1984). Furthermore, the drugs can be injected 


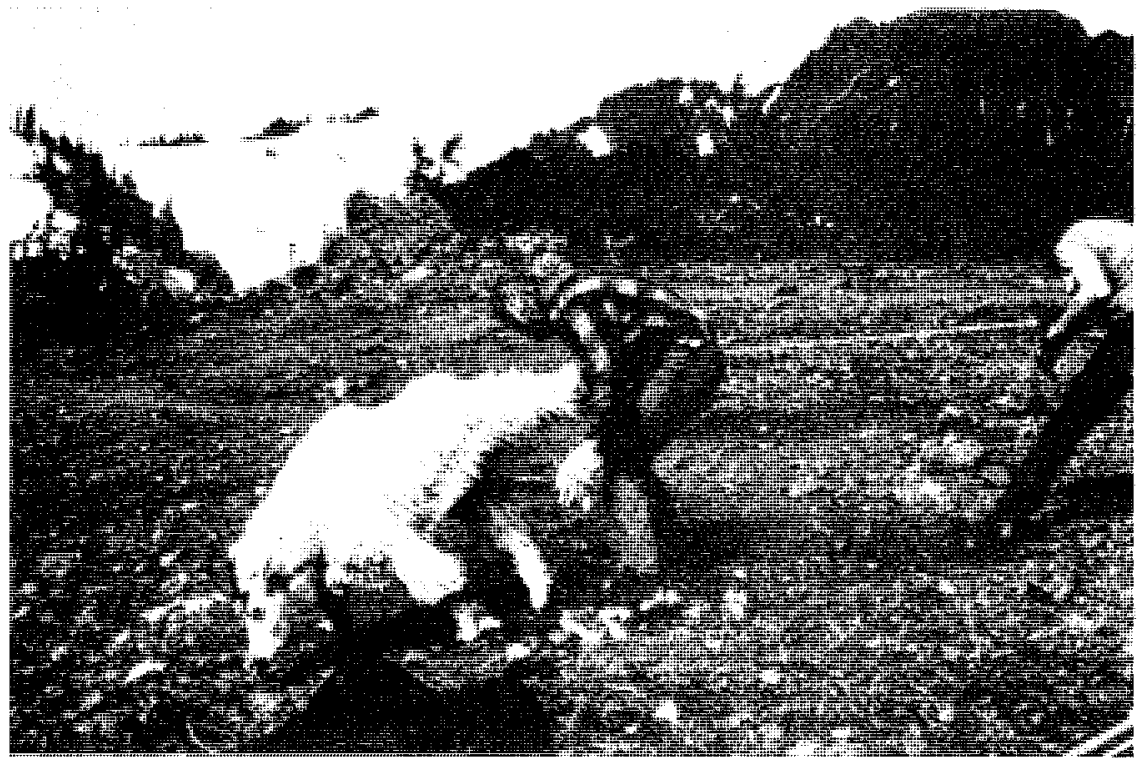

Figure 5. Biologists capture a mountain goat in Olympic National Park, Washington. To collect information essential to wildlife conservation it is often necessary to capture and handle animals or to mark them for individual identification. Despite numerous precautions, animals are sometimes injured during capture procedures.

(Photo: Daryll Hebert)

by dartfiring rifle, thus precluding the need for capture and handling. Similarly, Garrett and Franklin (1983) found that prairie dog (Cynomys ludovicianus) populations could be controlled by feeding the animals estrogen-laced grain. These colonially living rodents are highly seasonal breeders, and hormones need only be administered during a short period of time to have a significant impact on reproduction.

It would seem that such "benign" methods of population control offer some hope for compromise between the animal rights/welfare and environmental/ conservation movements. However, reproductive inhibition is a gradual rather than a rapid method of control. Environmental alteration can therefore be expected to continue until population size eventually decreases as a result of natural mortality (Hutchins et al. 1982). Thus, from the perspective of the environmental/conservation ethic, reproductive inhibition may be a case of "too little, too late," especially when one is dealing with long-lived animals that have relatively low mortality rates. By the time population growth can be curtailed, irreversible environmental changes may have already taken place.

Live capture and translocation is another non-lethal method of population control that is becoming increasingly popular with animal rights/welfare advocates. However, it also has numerous limitations. The animals are often 
subjected to considerable physical and psychological stress while being captured and transported (see "Conservation Research and Humane Concerns," below). Another major consideration is the fate of the animals that are being released. There have been few studies on this topic, but existing information suggests that many, if not the majority, of translocated deer die within a year of their release, presumably as a result of intraspecific competition (D. McCullough, personal communication). One of the most thorough studies on the fate of "translocated" mammals was conducted on marsupial gliders (Schoinobates volans) in Australia. One thousand of these animals were displaced to adjacent areas when their forest habitats were destroyed by logging (Tyndale-Briscoe and Smith 1969). A majority were recaptured shortly thereafter, but it was discovered that they had lost up to $25 \%$ of their body weight. Furthermore, many breeding females had lost their young. The adult mortality rate also appeared to be extremely high, as less than $7 \%$ of the emigrants were recaptured one year later. It was concluded..."that displaced sugar gliders die in situ rather than emigrate to occupied forest and die there through failure to become established" (ibid, p. 658). Thus, it is questionable whether translocations constitute a completely acceptable alternative to killing in terms of humane solutions.

Cost is a major obstacle to capture and removal schemes; however, a number of animal welfare groups have offered to provide the funding. For example, the Fund for Animals reportedly spent nearly $\$ 500,000$ to remove about 600 burros from Grand Canyon National Park (Newsweek 1981). These expenditures have been criticized as being short-sighted given the greater animal welfare interests that could be served if the money were used in other ways (Allen et al. 1981; Hutchins et al. 1982).

Some animal rights advocates might argue that most cases of animal overpopulation (whether the animals are exotic or indigenous) are ultimately caused by humans. Furthermore, they might ask why animals should be made to suffer for our mistakes. Conservationists would probably sympathize with this view but realize that wildlife does not exist in a vacuum. There are few areas left in the world that are unaffected by human activity. Indeed, most existing national parks and reserves are smaller than San Francisco's man-made Golden Gate Park. The small size of these reserves, and their isolation, make them particularly vulnerable to ecological disruption and disappearance of species (Soule et al. 1979; Miller 1979; Myers 1979; Ehrlich and Ehrlich 1981; Polunin and Eidsvik 1979).

To summarize, the rights view is characterized by a "laissez faire" attitude toward wildlife management. However, if the logic of the animal rights/ humane ethic is carried to its extreme, it would seem to require intervention when wild animals are suffering from starvation or disease (but, see Feinberg 1978). By contrast, total non-intervention is expected to be favored by the environmental/conservation ethic only when remnant ecosystems are relatively pristine and large enough for natural regulatory processes to operate (Cole 1971; Peek 1980). The environmental/conservation ethic would also 
favor direct population reductions under certain specific circumstances. For example, if some human-precipitated ecological change were to drive a population or species close to extinction, the environmental/conservation ethic would favor intervention, regardless of the consequences for individual animals. Furthermore, direct action would be deemed justifiable when, in the absence of natural checks and balances, a population of animals becomes so large that it threatens the existence of other species, or of the ecosystem as a whole. From the perspective of the environmental/conservation ethic, direct action would be particularly justifiable in national parks, wilderness areas, and equivalent reserves (see Younghusband and Myers 1986). These few areas constitute a relatively small portion of our total land area and contain the only remaining habitats that are still relatively pristine (Houston 1971).

\section{Incentives for Conserving Wildlife}

Incentives for preserving natural ecosystems, endangered species, and wildlife in general are complex (Erhlich and Erhlich 1981). Certainly moral and aesthetic considerations lie at one end of the spectrum (Gunn 1980; Regan 1983; Stone 1975; Blackstone 1978). More recently, however, there has been an increasing recognition of the economic value of wildlife and other natural "resources." Indeed, many conservationists and wildlife managers have invoked economics in an attempt to promote conservation efforts (Bart et al. 1979; Coe 1980; Myers 1979, 1980, 1981a; Ehrlich and Ehrlich 1981; Noonan and Zagata 1982). In contrast, the rights view is vigorously opposed to human exploitation of sentient animals for economic gain. According to Regan (1983, p. 343), "A practice, institution, enterprise, or similar undertaking is unjust if it permits or requires treating individuals with inherent value as if they were renewable resources." By contrast with the animal rights/humane ethic, the environmental/conservation ethic does not seek to eliminate all human exploitation of animals, provided that it be accomplished as humanely as possible and produces minimal impact on the environment (Leopold 1949; Myers 1979; Talbot 1980).

Some conservationists might argue that the rights view fails to consider the economic and political realities in which wildlife conservation must take place (Wilson 1984). Indeed, there are many examples in which the recognition of animals as "renewable resources" may have saved species from extinction. In Papua, New Guinea, for example, people who used to kill wild salt water crocodiles (Crocodylus porosus) are now raising them for sale in the world market (Montague 1981). The skins of these animals are among the most valuable of all crocodilians and, although they are still abundant in New Guinea, they have been hunted to extinction throughout most of their former range. Young crocodiles, which normally experience an $80 \%$ mortality rate in the wild, are brought into captivity, raised to optimum commercial size, and then killed humanely. Profits from such farming operations go directly to the local people, thus giving them an economic incentive for conservation. Without such rewards, there would be little chance that the species could survive. 
In the above example, conservation efforts were facilitated by peoples' perception of animals as renewable resources. Unlike non-renewable resources, renewable resources carr be expected to provide long-term economic gains. In the absence of such attitudes, people tend to opt for short-term exploitation strategies, and this is more likely to lead to extinctions (Hardin 1978). Myers (1979) states that conservation of species must take place in a world dominated by politics and economics. In such a world, arguments based solely upon abstract philosophical notions have only limited effectiveness. This is particularly true in developing nations where impoverished people and their governments have more immediate concerns. To people engaged in a daily struggle for survival, an endangered animal is usually seen as nothing more than a source of food or income.

Economic arguments for the preservation of species are focused on human needs, and such utilitarian notions about wildlife are unlikely to sit well with animal liberationists. Indeed, Singer (1981) has gone so far as to propose that the "circle of altruism" be expanded beyond our own species to all animals that can suffer or feel pain. Similar ideals have been expressed by Stone (1975), who argues that animals and, for that matter, whole ecosystems should be given not only moral standing but legal rights as well. Most conservationists would probably applaud such ideals, but there are many who consider them to be unrealistic. According to Wilson (1984, p. 131), "... to force the argument entirely inside the flat framework of kinship and legal rights is to trivialize the case for conservation." Wilson believes that the only way to make a conservation ethic work is to "ground it in ultimately selfish reasoning." The essential component of this principle is that people will conserve land and species if they "foresee a material gain for themselves, their kin, and their tribe" (ibid, pp. 131-132).

Conservationists generally do not believe that economic arguments should be invoked in every case. Indeed, there are many species that have no immediate cash value and are therefore classified as "non-resources." Thus, the danger in relying on economic arguments exclusively is that they might be effective only for a few valuable species (Ehrenfeld 1976; Leopold 1949; Myers 1979). Alternatively, certain valuable species may be poorly managed or over-exploited, thus hastening their extinction (see Domalain 1977). Conservationists are aware of these problems, and realize that economic arguments are but one of the many potential strategies in the struggle to preserve biological diversity (Ehrlich 1980).

\section{Conservation Research and Humane Concerns}

Scientific research is one means by which humans gain an understanding of the natural world. Such an understanding is essential to wildlife conservation efforts. In fact, Poole and Trefethen (1978, p. 344) have stated that "Knowledge is the essential prerequisite to making a management decision respecting a species, population, or group of wildlife." A decision made in the absence of information about a species or population, depending on the 
result, is, at worst, an act of ignorance, or, at best, a stroke of good fortune." With this in mind, it is important to ask: How should we view conservation research that harms individual animals?

Animal rights/welfare advocates have been traditionally opposed to the use of animals in biomedical research, particularly when individuals are sacrificed, or caused to suffer pain (March 1984; Singer 1975; Regan 1983). Indeed, Regan (1983, p. 385) has stated that "... animals are not to be treated as mere receptacles or as renewable resources. Thus does the practice of scientific research on animals violate their rights. Thus it ought to cease, according to the rights view."

By contrast with the animal rights/humane ethic, the more holistic environmental/conservation ethic would not oppose the use of animals in scientific research, particularly if such research were to help ensure the survival of a population,species, or ecosystem as a whole. However, animal rights advocates would consider this view to be "utilitarian," in that "whether the harm done to individual animals in the pursuit of scientific ends is justified depends on the balance of the aggregated consequences for all those affected by the outcome" (Regan 1983, p. 392).

There are many cases in which conservation research may prove harmful to individual animals. For example, to collect essential data on population dynamics, behavior, individual growth patterns, diseases, etc., it is often necessary to capture and handle animals, or to mark them for individual identification (figure 5; Taber and Cowan 1971). Despite numerous precautions by scientists, animals are sometimes injured or killed during capture procedures (Spraker 1978). For example, some animals suffer limb fractures and lesions as a result of falls, and some may succumb to an overdose of drugs or to shock (Stelfox 1976). Others may contract capture myopathy - an often fatal muscular disorder that is induced by the trauma of capture and transport (Chalmers and Barrett 1977; Spraker 1977, 1978).

Harm that comes to individual animals during capture and handling could be considered "accidental," in that scientists are not harming animals deliberately. However, there are cases in which conservation research may involve deliberate harm. For example, thousands of animals have been sacrificed so that biologists could analyze their stomach contents (e.g., Peterson 1955), or assess their physical condition or reproductive status (e.g., Parker 1981; Sinclair 1974). Another example is provided by the work of Eaton (1972a, $1972 \mathrm{~b}$ ), who studied the development of predatory behavior in captive-reared lions (Pantbera leo) and cheetahs (Acinonyx jubatus). To observe predation, he released live domestic goats, which were subsequently killed and eaten by the cats. The rights view certainly would not condone such experiments, yet, despite the unfortunate consequences for the individual goats, this work appears to be compatible with the more holistic environmental/conservation ethic. Many carnivorous species, including large predatory cats, have been forced to the brink of extinction by people (Stonehouse 1981). One method by which conservationists hope to save some of these species is through captive 
breeding and reintroduction (Brambell 1977). However, reintroducing captivebred animals into their natural habitats poses many difficult problems, includ. ing the ability of the animals to obtain their own food. Although young felids come equipped with an "instinctive" sequence of predatory behaviors, practice is necessary to increase efficiency (Leyhausen 1973). Live prey can be both unpredictable and dangerous and efficiency is important. Thus, a knowledge of how captive-bred predators learn to recognize potential prey, and how predatory behavior improves with practice, will be essential to any serious reintroduction effort (Bogue and Ferrari 1976).

The rights view would place heavy restrictions on the nature of conservation research. If carried to its logical extreme, it would, in fact, eliminate all science "that violates individual rights" (Regan 1983). One implication is that information essential to wildlife conservation could not be collected, and this might increase the probability of species extinctions. Animal rights/ welfare advocates might argue that scientists should work to develop more benign methods of study. In fact, scientists themselves have taken some initiative in this regard. There have, for example, been efforts to develop alternatives to tagging, branding, toe-clipping, and other types of identification techniques which involve harming animals (Ryder 1978). In addition, there has been an increased interest in the development of less invasive methods of assessing physical condition and diets. For example, physical condition can sometimes be assessed through measurements of weight, girth, blood chemistry, and horn growth rates (Bunnell 1978; Franzmann and LaResche 1978; Stevens 1983; Winters 1980). Similarly, dietary preferences can sometimes be determined by watching what animals eat (e.g., Hoeffs 1974), by analyzing feces (e.g., Owaga 1977), or by measuring the nutritional quality or abundance of the food resources themselves (e.g., Constan 1972; Miller 1974). The humane treatment of animals is therefore a continuing goal. However, it may not be possible to totally avoid suffering and pain. The problem of disappearing species is so acute and so immediate that there may not always be sufficient time to devote to such tasks.

\section{Conclusions}

Clearly, there are many cases in which the animal rights/humane ethic is in direct conflict with the environmental/conservation ethic. In fact, we consider the extreme views expressed by Singer (1975) and Regan (1983) to be largely incompatible with the goal of wildlife conservation. We agree with Wilson's (1984, p. 131) conclusion that the animal rights/welfare movement is due for "a stiffer dose of biological realism." In fact, the only major implication of modern biology that the humane moralists seem to have embraced is that of the evolutionary continuity between human beings and other forms of life (Callicott 1980). A recognition of our kinship with all living things is often used to argue that some nonhumans deserve "equal rights" (Singer 1981). However, other, less palatable, implications of the more holistic ecological/evolutionary perspective appear to have been conveniently 
ignored, especially when they conflict with the philosophic foundations of the animal rights/humane ethic (Callicott 1980; Rodman 1977).

As mentioned earlier, one of the major problems with the animal rights/ humane ethic is its focus on individual animals, as opposed to populations, species, or ecosystems. This reductionistic perspective of the natural world is biologically naive, and may itself be based on the cultural biases of its progenitors (Gunn 1980). Western cultures do tend to place more emphasis on the rights of individuals, as opposed to the welfare of society as a whole. Animal liberation is therefore an anthropomorphic philosophy (Rodman 1977), and this may explain some of its popular appeal. But what are the dangers of adopting a view of nature which is focused on the rights of individual organisms?

Myers (1979) and Ehrlich and Ehrlich (1981) have identified habitat destruction as the most significant threat to wild animal populations. Therefore, a concern for wild animals needs to be expressed in a willingness to protect natural ecosystems. On a superficial level animals appear to be separate entities, moving independently and freely within their environments. In fact, nothing could be further from the truth. All free-living organisms are closely tied to the habitats in which they have evolved. It is therefore difficult to separate individuals from their ecological contexts (Fox 1979). Similarly, it is equally difficult to draw strong distinctions between living and nonliving things. All living organisms, whether they be viruses or humans, are composed of non-living matter. Carnivores, for example, are as dependent on soils for their existence as they are on their prey.

In simple terms, an ecosystem must consist of a source of energy (usually sunlight), a source of raw chemical materials (rocks, soil, air, and water), "producers" capable of transforming and storing solar energy (usually green plants), "primary consumers" which feed on the producers (i.e., herbivores), "secondary consumers," which feed on the primaty consumers (i.e., carnivores) and, finally, decomposers which break down the dead bodies of the producers and consumers and cycle their energy back into the system (Dasmann 1978). According to Leopold (1949), such "food chains are the living channels which conduct energy upward; death and decay return it to the soil ... like a slowly augmented revolving fund of life." The rights view simply cannot deal with such complex interdependencies. To quote Rodman (1979, p. 89), "The moral atomism that focuses on animals and their subjective experiences does not seem well adapted to coping with ecological systems."

The humane moralists are very specific about which forms of life are to be granted full moral consideration. Indeed, many ardent defenders of animal rights have focused exclusively on the protection of sentient animals, and often their attention is concentrated only on those animals that are perceived as being appealing or "cute" (Neitschmann 1977; Rodman 1977). Fox (1979) has recognized the apparent weakness of this philosophy, noting that "The ecological imperative of responsible stewardship concerns our relationship with all of creation, both sentient and non-sentient" (p. 54). He envisions 
the animal welfare movement as being an important transition to a more holistic "eco-ethic." While we agree that a recognition of the "rights" of all living things is an important step toward the attainment of such a goal, we also stress that responsible stewardship may involve difficult, and sometimes painful decisions (see Fox 1978; Hutchins et al. 1982). In some cases, our actions may result in the death or suffering of other sentient beings. Of course, this does not imply that animals can be treated without care and respect. For example, when the need to control an animal population has been identified, it should be accomplished in the most humane manner possible, given the limitations of the situation. However, when the purpose of such reductions is to preserve natural ecosystems or to protect endangered animals or plants, then it should not be perceived as being "inhumane."

Regan (1983) has labelled any attempt to subvert the rights of individual organisms to the species or ecosystem as "environmental fascism." However, the more appropriate term might be "environmental socialism," in that the "rights" of individual animals are viewed as secondary to those of the species or ecosystem as a whole. From the perspective of the environmental/conservation ethic, the species and ecosystem are more important than any one organism. Indeed, without the former, there is no way that the latter could even exist! As Soule and Wilcox (1980, p. 8) have pointed out, "Death is one thing-an end to birth is something else." In fact, if animal rights/welfare advocates are unwilling to broaden their perspective to encompass the whole of nature, they will risk a total alienation of the environmental community. Moreover, "in adhering to a philosophy that emphasizes a reverence for life, but that ignores the conditions necessary for its survival, they may ultimately be unfaithful to their own ideals" (Hutchins et al. 1982, p. 333). In this respect, radical animal liberationists may have much in common with certain Hindu castes. Based on his travels in India, Sanderson (1896, p. 160) once wrote that "Many natives would not hurt the meanest insect: but though it might be merciful to put an end to suffering in many cases they cannot part from their disinclination to take life." The frustration of the colonial British with Hindu ethics illustrates an important point: A belief system that protects a well-meaning person's conscience may in fact perpetuate a greater suffering unknown to him or her (also see Rodman 1979; Callicott 1980).

Conservationists and animal liberationists have challenged our traditional perceptions of non-human animals (Wilson 1984). However, the latter view is biologically illiterate and thus ill-equipped to provide an intelligent basis for wildlife conservation. This is not to imply that our relationship with nature should never be approached in moral terms. In fact, ethical philosophy faces a severe test when it comes to the conservation problem. As Wilson (1984, p. 123) has written, "... in ecological and evolutionary time, good does not automatically flow from good or evil from evil. To choose what is best for the near future is easy. To choose what is best for the distant future is also easy. But to choose what is best for both the near future and distant future is a hard task, often internally contradictory, and requiring ethical codes yet to be formulated." 


\section{Epilogue}

The objective of this paper was to compare the animal rights/humane and environmental/conservation ethics, and review potential conflicts. Though it is clear that there are significant differences in values, it is also clear that the two views are not completely antithetical. The primary difference between the two ethics lies in the scope and the primacy of their concerns. We hope, however, that this essay has not been a purely intellectual exercise, and would therefore like to explore the potential for reconciliation. Indeed, we believe that a shared appreciation of those values held in common could lead to productive compromises benefiting both wildlife and environment. As it is now, there is a strong element of evangelism among animal rights/humane proponents which views any compromise as concession, and an equally stubborn element exists among certain environmental/conservation groups.

Enlightened solutions to the problems of the humane treatment of animals and environmental concern can best be achieved through collaboration. Participation in cooperative problem solving through regular meetings, workshops, and symposia should enhance awareness of concerns vital to each group's interests. 'This is a significant challenge which has yet to be confronted on a useful scale. Already there have been some efforts, such as the international workshop on the problem of overabundant animals (Jewell et al. 1981). Cooperation will also permit the pooling of resources necessary to test the efficacy of humane alternatives to conventional, but disputed animal management techniques. Success in achieving mutually acceptable solutions will depend on strong and enlightened leadership on both sides, which shares the conviction that lasting solutions to complex problems cannot be found in isolation.

If we are truly concerned about the welfare of wild animals, we must also begin to question our own behavior. For example, some animal rights/welfare advocates have expressed their concern for animals by attempting to thwart recreational hunters (Relnecke 1983). Yet, in comparison with other, more "subtle" human activities, properly regulated hunting has little impact on animal welfare or wildlife conservation efforts. In fact, the long-term goals of conservationists and animal liberationists would best be served by radical changes in human life-styles (Ehrlich and Ehrlich 1981; Myers 1981b). The two greatest challenges facing preservationists today are: (1) the selfish, materialistic, and often wasteful attitudes prevalent in developed nations, like the United States, and (2) rampant population growth in the so-called Third World countries (Ehrlich 1980). Movement toward a steady state economy and zero population growth would do more for the welfare of animals than all our other efforts combined. If current trends in human population growth and habitat destruction continue, we could lose nearly one million species of animals and plants in the next two decades alone (Myers 1979, 1985; Ehrlich and Ehrlich 1981). This fact makes it even more essential that those who care about wildlife and nature, and those who care about the rights of individual animals close ranks to do battle with a common enemy. 


\section{Acknowledgements}

We thank D.P. Barash, W. Conway, C. Crockett, P. Hardiston, G. Orians, and R.D. Taber for reviewing and commenting on the manuscript.

\section{Endnotes}

${ }^{1}$ Curatorial Intern, Department of Mammalogy, New York Zoological Society, Bronx, NY 10460.

${ }^{2}$ Assistant Director for Conservation and Captive Breeding, Conservation and Research Center, National Zoological Park, Smithsonian Institution, Front Royal, VA 22630.

\section{References}

Allen, DL, Erickson, L, Hall, ER and Shirra, WM. 1981. A review and recommendations on animal problems and related management needs in units of the National Park System. Report to the Secretary of the Interior. Mimeo, $18 \mathrm{pp}$.

Anderson, TE. 1971. Identifying, evaluating, and controlling wildlife damage. In: Giles, RH. ed. Wildlife Management Techniques. Washington, DC: The Wildlife Society.

Baker, JK and Reeser, DW. 1972. Goat management problems in Hawaii Volcanoes National Park. U.S. Dept. Int. Nat. Res. Rep. 2: 1-22.

Bart, J, Allee, D and Richmond, M. 1979. Using economics in defense of wildlife. Wildl. Soc. Bull. 7(3): 139-44.

Beach, FA 1975. Beasts before the bar. In: Ternes, A ed. Ants, Indians, and Little Dinosaurs. New York: Charles Scribner's Sons.

Blackstone, WT. 1978. Is there an environmental ethic? In: Blackstone, WT. ed. Pbilosophy and Environmental Crisis. Athens, GA: Univ. of Georgia Press.

Blonston, G. 1983. Where nature takes its course. Science 83. 4(9): 45-55.

Bogue, G and Ferrari, M. 1976. On the predatory "training" of captive-reared pumas. Carnivore. $3(1): 36-45$.

Brambell, MR. 1977. Reintroduction. Int. Zoo Ybk. 17: 112-16.

Buechner, HK and Dawkins, HC. 1961. Vegetation change induced by elephants and fire in Murchison Falls National Park,Uganda. Ecology. 42(4): 752-66.

Bunnell, FL. 1978. Horn growth and population quality in Dall sheep.J. Wildl. Manage. 42: 764-75.

Callicott, B. 1980. Animal liberation: A triangular affair. Env. Ethics. 2: 311-38.

Carothers, SW, Stitt, ME and Johnson, RR. 1976. Feral asses on public lands: Analysis of biotic impact, legal considerations and management alternatives. In:Trans. 41st North Am. Wildl. Conf. pp. 396-406.

Caughley, G. 1970. Wildlife management and the dynamics of ungulate populations. Appl. Biol. 1: $183-246$.

-. 1976. The elephant problem - an alternative hyphothesis. E. Afr. Wildl. J. 14: 265-83.

-. 1981. Overpopulation. In: Jewell, PA and Holt, S. eds. Problems in Management of Locally Abundant Wild Mammals. New York: Academic Press.

Chalmers, GA and Barrett, MW. 1977. Capture myopathy in pronghorns in Alberta. J. Am. Vet. Assoc. 171: 918-23.

Chase, A 1986. Playing God in Yellowstone. Boston: The Atlantic Monthly.

Cheatum, EL. 1951. Disease in relation to winter mortality of deer in New York. J. Wildl. Manage. 15: 216-20.

Christian, JJ and Davis, DE. 1964. Endocrines, behavior, and population. Science. 146: 1550-60.

Coblentz, B. 1978. The effects of feral goats on island ecosystems. Biol. Conserv. 13: 279-86.

Coe, M. 1980. African wildlife resources. In: Soule, ME and Wilcox, BA. eds. Conservation Biology: An Evolutionary Ecological Perspective. New York: Sinauer. 
Cole, GF. 1971. An ecological rationale for the natural or artificial regulation of native ungulates in parks. Trans. North Am. Wildl. Res. Conf. 36: 417-25.

Constan, KJ. 1972. Winter food and range use of three species of ungulates. J. Wildl. Manage. 36(4): $1068-76$.

Courtney, WR. 1978. The introduction of exotic organisms. In: Brokaw, HP. ed. Wildlife and America. Washington, DC: U.S. Fish and Wildlife Service.

Courtney, WR and Ogilvie, VE. 1971. Species pollution. Anim. Kingdom. 74(2): 22-28.

Cumming, DH. 1981. The management of elephant and other large mammals in Zimbabwe. In: Jewell, PA and Holt, S. eds. Problems in Management of Locally Abundant Wild Mammals. New York: Academic Press.

Dasmann, RF. 1978. Wildlife and ecosystems. In: Brokaw, HP. ed. Wildlife and America. Washington, DC: Council for Environmental Quality.

Davis, DE. 1961. Principles of population control by gametocides. Trans. North Am. Wildl. Nat. Res. Conf. 26: 160-67.

deVos, A and Petrides, GA. 1967. Biological effects caused by terrestrial vertebrates introduced into non-native environments. In: Towards a New Relationship of Man and Nature in Temperate Lands. Part III: Changes Due to Introduced Species. Morges, Switzerland: International Union for Conservation of Nature and Natural Resources (IUCN).

Domalain, J. 1977. Confessions of an animal trafficker. Nat. Hist. 86: 54-67.

Eaton, RL. 1972a. An experimental study of predatory and feeding behavior in the cheetah (Acinonyx jubatus) Zeit. Tierpsycbol. 31: 270-80.

-. 1972b. Predatory and feeding behavior in adult lions: The deprivation experiment. Zeit. Tierpsychol. 31: 46173.

Ehrenfeld, DW. 1972. Conserving Life on Earth. New York: Oxford University Press.

-. 1976. The conservation of non-resources. Amer. Sci. 64(6): 648-56.

Ehrlich, PR. 1980. The strategy of conservation, 1980-2000. In: Soule, ME and Wilcox, BA. eds. Consenvation Biology: An Evolutionary-Ecological Perspective. New York: Sinauer.

Ehrlich, P and Ehrlich, A. 1981. Extinction. New York: Random House.

Feinberg, J. 1978. Human duties and animal rights. In: Morris, RK and Fox, MW. eds. On the Fifth Day: Animal Rights and Human Etbics. Washington, DC: The Humane Society of the United States.

Fenner, F and Ratcliffe, FN. 1965. Myxomytosis. Cambridge, England: Cambridge University Press.

Fenner, F. 1980. A welcome extinction. Env. Conserv. 7(3): 174-75.

Fox, MW. 1978. Man and nature: Biological perspectives. In: Morris, RK and Fox, MW. eds. On the Fifth Day: Animal Rights and Human Ethics. Washington, DC: The Humane Society of the United States.

-. 1979. Animal rights and nature liberation. In: Paterson, D and Ryder, RD. eds. Animal Rights-A Symposium. Sussex, England: Centaur Press.

Franzmann, AW and LaResche, RE. 1978. Alaskan moose blood studies with emphasis on condition evaluation. $J$. Wildl. Manage. 42: 334-51.

Garrett, MG and Franklin, WL. 1983. Diethylstilbestrol as a temporary chemosterilant to control black-tailed prairie dog populations. J. Range Manage. 36(6): 753-56.

Gould, SJ. 1982. Non-moral nature. Nat. Hist. 91(2): 19-26.

Grandy, JW. 1982. The Everglades deer massacre ... and its aftermath. The Humane Society News. 27(4): 34-35.

Gunn, AS. 1980. Why should we care about rare species? Env. Ethics. 2: 17-37.

Haigh, JC, Parker, IS, Parkinson, DA and Archer, AL. 1979. An elephant extermination. Env. Conserv. 6(4): 305-10. 
Hamann, O. 1979. Regeneration of vegetation on Santa Fe and Pinta Islands, Galapagos after the eradication of goats. Biol. Conserv. 15: 215-36.

Hanley, TA and Brady, WW. 1977. Feral burro impact on a Sonoran Desert range. J. Range Manage. 30: 374-77.

Hansen, RM. 1980. Habitat. In: Monson, G and Sumner, L. eds. The Desert Bigborn. Tucson, AZ: Univ. of Arizona Press.

Hardin, G. 1974. Living in a lifeboat. Bioscience. 24: 561-68.

-. 1978. Political requirements for preserving our common heritage. In: Brokaw, HP. ed. Wildlife and America. Washington, DC: Council on Environmental Quality.

Hoeffs, M. 1974. Food selection by Dall's sheep(Ovis dalli dalli Nelson). In: Geist, V and Walther, F. eds. The Bebaviour of Ungulates and Its Relation to Management. Vol. II. Morges, Switzerland: IUCN.

Holdgate, MW. 1967. The influence of introduced species on the ecosystems of temperate oceanic islands. In: Towards a New Relationship of Man and Nature in Temperate Lands. Part III: Changes Due to Introduced Species. Morges, Switzerland: IUCN.

Hope, JE. 1974. Hunters; Useful pruners of nature or just killers? Smithsonian. 4(10): 78-82.

Houston, DB. 1971. Ecosystems of national parks. Science. 172: 648-51.

- 1982. The Northern Yellowstone Elk: Ecology and Management. New York: MacMillan.

Howard, WE. 1964. Introduced browsing animals and habitat stability in New Zealand. J. Wildl. Manage. 28(3): 42129.

- 1967. Ecological changes in New Zealand due to introduced animals. In: Towards a New Relationship of Man and Nature in Temperate Lands. Part III: Changes Due to Introduced Species. Morges, Switzerland: IUCN.

Humane Society Nerus. 1983. The hunt that wasn't: The HSUS plays a major role in halting the National Zoo deer hunt. 28(1): 8-9.

Hutchins, M, Stevens, V and Atkins, N. 1982. Introduced species and the issue of animal welfare. Int. J. Stud. Anim. Prob. 3(4): 318-36.

Iker, S. 1983. Swamped with deer. Natl. Wildl. 21(6): 5-11.

Janzen, DH. 1978. New horizons in the biology of plant defenses. In: Rosenthal, GA and Janzen, DH. eds. Herbivores: Their Interaction with Secondary Plant Metabolites. New York: Academic Press.

Jewell, PA, Holt, S and Hart, D. eds. 1981. Problems in Management of Locally Abundant Mammals. New York: Academic Press.

Johnson, E and Tait, AJ. 1983. Prospects for the chemical control of reproduction in the Grey squirrel. Mammal Rev. 13: 167.72.

Kenelly, D, Johns, BE and Garrison, MV. 1970 . Fecundity of a Norway rat colony with $85 \%$ sterile males. Ann. Meet. of the Soc, for the Study of Reproduction. Abstract.

Klein, DR. 1981. The problems of overpopulation of deer in North America. In: Jewell, PA and Holt, S. eds. Problems in Management of Locally Abundant Wild Mammals. New York: Academic Press.

Laws, RM. 1970. Elephants as agents of habitat and landscape change in East Africa. Oikos. 21: 1-15.

—. 1974. Behaviour, dynamics and management of elephant populations. In: Geist, V and Walther, $\mathrm{F}$. eds. The Bebaviour of Ungulates and Its Relation to Managment. Vol. II. Morges, Switzerland: IUCN.

Laycock, G. 1966. The Alien Animals. New York: Natural History Press.

—. 1974. Dilemma in the desert: Burros or bighorns? Audubon. 76(5): 116-77.

—. 1984. A scourge of goats. Audubon. 86(1): 10003.

Leopold, A, Sowls, LK and Spencer, DL. 1947. A survey of overpopulated deer ranges in the United States. $J$. Wildl. Manage. 11: 162-77.

Leopold, A. 1949. A Sand County Almanac. New York: Oxford University Press.

Leyhausen, P. 1973. On the function of the relative hierarchy of moods (as exemplified by the phylogenetic and ontogenetic development of prey-catching in carnivores). In: Lorenz, $\mathrm{K}$ and Leyhausen, P. eds. Motivation of Human and Animal Bebavior New York: Van Nostrand Reinhold. 
Lopez, B. 1978. Of Wolves and Men. New York: Charles Scribner's Sons.

Lyons, G. 1978. Politics in the woods. Harper's. 257: 27-38.

Madson, C. 1986. To feed or not to feed. Audubon. 88(2): 22-27.

March, BE. 1984. Bioethical problems: Animal welfare, animal rights. Bioscience. 34(10): 615-20.

Matsche, GH. 1976. Non-efficiency of mechanical birth control devices for white-tailed deer. J. Wildl. Manage. 40(4): 792-95.

- 1977a. Micro-encapsulated diethylstilbestrol as an oral contraceptive in white-tailed deer. J. Wildl. Manage. 41(1): 87-91.

—. 1977b. Fertility control in white-tailed deer by steroid implants. J. Wild. Manage. 41(4): 731.

- . 1980. Efficacy of steroid implants in preventing pregnancy in white-tailed deer. $J$. Wildl. Manage. 44(3): 756-58.

McCullough, DR, 1979. The George Reserve Deer Herd:Population Ecology of a K-selected Species. Ann Arbor, MI: Univ. of Michigan Press.

Meagher, M. 1982. An outbreak of pinkeye in bighorn sheep: A preliminary report. Bienn. Symp. North Wild Sheep and Goat Council. 3: 198-201.

Midgley, M. 1983. Animals and Why They Matter. Athens, GA: Univ. of Georgia Press.

Miller, DR. 1974. Seasonal changes in the feeding behaviour of barren-ground caribou on the Taiga winter range. In: Geist, V and Walther, F eds. The Bebaviour of Ungulates and Its Relation to Management. Vol. II. Morges, Switzerland: IUCN.

Miller, RI. 1979. Conserving the genetic integrity of faunal populations and communities. Env. Conserv. 6(4): 297-304.

Montague, J. 1981. His "crop" is crocodiles. Int. Wildl. 11(2): 21-28.

Myers, N. 1979. The Sinking Ark. New York: Permagon Press.

—. 1980. The problem of disappearing species: What can be done? Ambio. 9: 229-35.

- 1981a. A farewell to Africa, $n t$. Wildl. 11(6): 36-46.

- 1981b. The hamburger connection: How Central America's forests become North America's hamburgers. Ambio. 10: 38.

-. 1985. The end of the lines. Nat. Hist. 94(2): 2-12.

National Wildlife. 1971. Hunters and conservationists share goals. $9(6)$ : 18-19.

Newsweek. 1981. Wild burros still under fire.97(15): 17-18.

Nietschmann, B. 1977. The Bambi factor. Nat. Hist. 86(7): 84, 86, 87.

Noonan, PF and Zagata, MD. 1982. Wildlife in the market place: Using the profit motive to maintain wildlife habitat. Wildl. Soc. Bull. 10(1): 46-49.

Noy-Meir, I. 1981. Responses of vegetation to the abundance of mammalian herbivores. In: Jewell, PA and Holt, S. eds. Problems in Management of Locally Abundant Wild Mammals. New York: Academic Press.

Owaga, ML. 1977. Comparison of analysis of stomach contents and fecal samples from zebra. E. Afr. Wildl. J. 15: 21722.

Parker, GR. 1981. Physical and reproductive characteristics of an expanding woodland caribou population (Rangifer tarandus tarandus) in northern Labrador. Can. J. Zoo. 59: 192940.

Peek, JM. 1980. Natural regulation of ungulates (What constitutes a real wilderness?). Wildl. Soc. Bull. 8(3): 217-27.

Peterson, RL. 1955. North American Moose. Toronto: Univ. of Toronto Press.

Pianka, ER. 1983. Evolutionary Ecology. 2nd edition. New York: Harper and Row.

Pienaar, U. de V. 1969. Why elephant culling is necessary. Afr. Wildl. 23: 181-84.

Poche, RW. 1980. Elephant management in Africa. Wildl. Soc. Bull. 8(3): 199-207.

Polunin, N and Eidsvik, HK. 1979. Ecological principles for the establishment and management of national parks and equivalent resources. Env. Conserv. 6(1): 21-26.

Poole, DA and Trefethen, JB. 1978. The maintenance of wildlife populations. In: Brokaw, HP. ed. Wildlife and America. Washington, DC: Council on Environmental Quality.

Rasmussen, DI. 1941. Biotic communities of Kaibab Plateau, Arizona, Ecol. Monogr. 11:230-75.

Regan, T. 1983. The Case for Animal Rights. Berkeley, CA: Univ. of California Press.

Reiger, G. 1978. Wild boars, burros, horses cause park service apoplexy. Audubon. 80(3): 119-22. 
Relnecke, B. 1983. Hunters become the hunted: Animal lovers turn the tables. The Seattle Times. Wednesday, March 16.

Remfrey, J. 1978. Control of feral cat populations by long term administration of megastrol acetate. Vet. Rec. 28: 403-04.

Robbins, J. 1984. Do not feed the bears? Nat. Hist. 93(1): 12-21.

Robinson, WL, Fanter, LH, Spalding, AG and Jones, SL. 1980. Biological aspects of political mismanagement of white-tailed deer in Pictured Rocks National Seashore. Proc. 2nd Conf. on Scientific Res. in National Parks. pp.283-92.

Rodman, J. 1977. The liberation of nature? Inquiry. 20: 83-131.

Ryder, RD. 1978. Postscript: Towards humane methods of identification. In: Stonehouse, B. ed. Animal Marking: Recognition Marking of Animals in Researcb. London: MacMillan Press Ltd.

Sanderson, GP. 1896. Thirteen Years Among the Wild Beasts of India. London: W.H. Allen and Co.

Schectman, SM. 1978. The "Bambi syndrome": How NEPA's public participation in wildlife management is hurting the environment. Env: Law: 8: 611-43.

Seal, US, Barton, R, Mather, L, Olberding, K, Plotga, BD and Gray, CW. 1976. Hormonal contraception in captive female lions (Pantbera leo). J. Zoo Anim. Med. 7(4): 12-20.

Shaw, Ww. 1974. Meanings of wildlife for Americans: Contemporary attitudes and social trends. Trans. North Am. Wildl. Nat. Res. Conf. 39: 151-55.

Sinclair, AR. 1974. The natural regulation of buffalo poptiations in East Africa. II. Reproduction, recruitment and growth. E. Afr. Wildl. J. 12: 169-83.

-. 1981. Environmental carrying capacity and the evidence for overabundance. In: Jewell, PA and Holt, S. eds. Problems in Management of Locally Abundant Wild Mammals. New York: Acadenic Press.

Singer, P. 1975. Animal Liberation. New York: Avon Books.

-. 1981. The Expanding Circle: Etbics and Sociobiology. New York: Farrar, Straus, and Giroux.

Soule, ME, Wilcox, BA and Holtby, C. 1979. Benign neglect: A model of faunal collapse in the game reserves of East Africa. Biol. Conserv. 15: 259-72.

Soule, ME and Wilcox, BA. 1980. Conservation biology: Its scope and its challenge. In: Soule, ME and Wilcox, BA. ed. Conservation Biology: An Evolutionary-Ecological Perspective. Sunderland, MA: Sinauer.

Spraker, TR. 1977. Capture myopathy of Rocky Mountain bighorn sheep. In: Trans. Desert Bighorn Sheep Council 1977. pp. 14-16.

- 1978. Pathophysiology associated with capture of wild animals. In: Montali, RJ and Migaki, G. eds. The Comparative Pathology of Zoo Animals. Symp. Natl. Zool. Park. Washington, DC: Smithsonian Institution.

Stelfox, JG. 1976. Immobilizing bighorn sheep with succinycholine chloride and phencyclidine hydrochloride. J. Wildl. Manage. 40(1): 174-76.

Stevens, V. 1983. The dynamics of dispersal in an introduced mountain goat population. Ph.D. Dissertation. Univ. of Washington, Seattle, WA.

Stocker, J. 1980. Battle of the burro. Natl. Wildl. 19(5): 14-16.Stone, CD. 1975. Sbould Trees Have Standing? New York: Discus Books.

Stonehouse, B. 1981. Saving the Animals. New York: MacMillan.

Taber, RD and Cowan, IMCT. 1971. Capturing and marking wild animals. In: Giles, RH. ed. Wildilife Management Techniques. Washington, DC: Wildlife Society.

Talbot, LM. 1980. The world's conservation strategy. Env. Conserv. 7(4): 259-68.

Taylor, WP and Hahn, HC. 1947. Die-offs among white-tailed deer in the Edwards Plateau of Texas. J. Wildl. Manage 11(4): 317-23.

Tennesen, M. 1975. Bighorn on the run. Natl. Wildl. 13(6): 4-10.

Tyndale-Biscoe, CH and Smith, RF. 1969. Studies on the narsupial glider, Schoinobates volans (Kerr). III. Response to habitat destruction. J. Anim. Ecol. 38: 65159.

Turner, JW. 1984. Given a free rein, prolific mustangs gallop into trouble. Smithsonian. 14(11): 88-96. 
U.S. Dept. of the Interior. 1980. Feral Burro Management and Ecosystem Restoration Plan and Final Environmental Assessment. Grand Canyon National Park: National Park Service.

Van Wyk, P and Fairall, N. 1969. The influence of the African elephant on the vegetation of the Kruger National Park with special reference to tree and shrub strata. Koedoe. 12: 57-89.

Walters, JE and Hansen, RM. 1978. Evidence of feral burro competition with desert bighorn sheep in Grand Canyon National Park. In: Trans. Desert Bighom Sheep Council 1978. pp. $10-16$.

Wardle, RE. 1974. Influence of introduced mammals on the forest and shrublands of the Grey River Headwaters. NZJ Sci. 4(3): 459-86.

Warner, RE. 1963. Recent history and ecology of the Laysan duck. Condor. 65: 3-23.

White, L. 1967. The historical roots of our ecologic crisis. Science. 155; 1203-07.

Whitlock, B. 1978. Seasonal use of ovaban as a means of contraception in the Kodiak bear. Proceedings of the Annual Meeting of the American Association of Zoo Veterinarians, 1978. pp. 178-80.

Wilson, DE and Hirst, SM. 1977. Ecology and factors limiting roan and sable antelope populations in South Africa. Wildl. Monogr. 54: 1-111.

Wilson, EO. 1984. Biophilia: The Human Bond with Other Species. Cambridge, MA: Harvard University Press.

Winters, JF. 1980. Summer habitat and food utilization by Dall's sheep and their relation to body and horn size. M.S. Thesis. Univ. of Alaska, College, AK.

Wright, P. 1978. Why must we euthanize? The Humane Society News. 23(11): 24-25.

Younghusband, P and Myers, N. 1986. Playing God with nature. Intl. Wildl. 16(4): 4-13.

Zwank, PJ. 1981. Effects of field laparotomy on survival and reproduction in mule deer. $J$. Wildl. Manage. 45(4): 972-75 